\title{
The Environmental Sustainability Concerning Exploitation of Oil and Gas Based on Law in Indonesia
}

\author{
Hiday ati \\ Student at Doctoral Program of Law \\ Universitas Borobudur \\ Jakarta, Indonesia \\ hidayatia665@gmail.com
}

\author{
Faisal Santiago \\ Faculty of Law \\ Universitas Borobudur \\ Jakarta, Indonesia \\ faisalsantiago@borobudur.ac.id
}

\begin{abstract}
Oil and Gas itself has a very strategic value for the life of the Indonesian people as a source of domestic energy and a very significant source of state revenue. However, various policies on Oil and Natural Gas issued by the government are still considered not able to elaborate the challenges and problems of oil and gas reserves. Beside the importance of oil and gas to help the Indonesian economy, it has negative effects on the surrounding environment. That is waste caused by oil and gas production. Supposedly, the development of the oil and gas sector can go hand in hand with development in the environmental sector. The creation of a balance between the utilization and sustainability of forests and oil as well as gas is an important prerequisite for the implementation of sustainable development of the environment as well as oil and gas sectors. This study will discuss: how is the protection of environmental sustainability of oil and gas exports under the law in Indonesia? The study shows that Indonesian law is not clear and firm enough in arrangement for oil and gas industry related to its obligation to preserve the environment. Various cases of environmental damage that occurred which are caused by the oil and gas industry are evidences that the existing rules have not been implemented maximally.
\end{abstract}

Keywords - sustainability, environment, law

\section{INTRODUCTION}

Indonesia is a country which is rich in minerals (mining). The minerals include gold, silver, copper, oil and natural gas, and others. The natural wealth belonging to the people of Indonesia which is empowered to the state is mandated to be managed well in order to achieve the goals of the state of Indonesia. Government as a representation of the state is given the right to manage the wealth of natural resources to be enjoyed by the people in fair and equitable manner. The prosperity of the people is the spirit and the ultimate ideals of the welfare state that must be realized by the state and the government of Indonesia. Natural resource management is one of the instruments to achieve it.

In the 1945 Constitution Article 33 paragraph (3) has mandated and states that:

"The earth, the water, and the natural wealth contained therein are controlled by the State and used for the greatest prosperity of the people."
This means that the management of natural resources or natural resources contained within the state should be used as much as possible for the welfare of the people. The natural resources contained therein include oil and natural gas which are unrenewable resources and extremely rare.

Oil and Gas itself has a very strategic value for the life of the Indonesian people as a source of domestic energy and a very significant source of state revenue. However, various policies on Oil and Natural Gas is sued by the government are still considered not able to elaborate the challenges and problems of oil and gas reserves. The Oil and Gas Industry in Indonesia has a very important role in the Indonesian economy. Although its role has actually started since 1856 , it was not until 1958 that the industry began to donate to the state of RI. The potential of Indonesia's estimated petroleum resources is estimated at around 50 billion barrels. With the current production rate calculation (1.2 million - 1.3 million barrels per day according to OPEC quota 1984) the potential of such resources would be sufficient to be utilized for more than a century.

But behind the importance of oil and gas to help the Indonesian economy there are negative effects on the environment. That is waste caused by oil and gas production. In addition, oil and gas production also has a great effect in case of leakage, for example that has occurred in PT.Lapindo Brantas in Porong Sidoarjo. This of course gives great effect to human life as well as nature, because besides destroying nature and destroying part of the house of the people, this has an impact on social life and land dispute due to the victims of gas leak which has been mixed with mud [1].

Oil and gas business activities should be conducted based on populist economy, integrity, benefits, justice, equity, equity, common prosperity and welfare of the people, security, safety, and legal certainty and environmental insight. Supposedly, the development of the oil and gas sector can go hand in hand with development in the environmental sector. The creation of a balance between the utilization and sustainability of forests and oil and gas is an important prerequisite for the implementation of sustainable development of the environment and oil and gas sectors.

\section{PROBLEM}

The crimes committed in the case of natural resources and the environment are a crime that does not stop when the 
perpetrator succeeds in jail into the prison or compensation. This crime will have an accumulative impact and tend to give rise to a new form of crime. One concrete example of the simple environmental destruction of forest destruction which could then create a series of disasters such as floods, landslides, droughts, crop failures, crop failures and forest fires. Even the effects of destructive logging can lead to the loss of life and property to those affected by such disasters. Therefore in this study will be discussed about how the protection of environmental sustainability of oil and gas exploitation which is based on the law in Indonesia?

\section{DISCUSSION}

\section{A. The meaning of Exploration and Exploitation.}

Exploitation and exploration of natural resources are colored by a paradigm that assesses natural resources as revenue rather than capital. The paradig $m$ has evolved long before the industrial revolution as an investment of the human desire to dominate the realm of necessity to each other towards a better quality of life. The implications of worldview which is conscious or not have shaped the production of all economic activity including the exploitation and exploration of natural resources mining. As far as the exploration of natural resources is still the explanation of the above paradigm. Exploitation of natural resources is only directed to support economic growth without regarding its balance.

Exploration is a field investigation to collect data / information as complete as possible about the existence of natural resources somewhere. Exploration activities are very important to be carried out before the mining operations are carried out considering the existence of uneven distribution of the excavated materials which is temporarry and one day will be exhausted. So to determine the location of the distribution, the quality and the amount of reserves and how to take it requires careful investigation in order not to waste energy and capital, in addition to reduce the risk of failure, material loss, work accidents and environmental damage.

Exploitation is a mining business with the intention to produce minerals and utilize them. This activity can be distinguished by the nature of the excavation materials, dug excavation and liquid and gas excavation materials.

\section{B. The meaning of Oil and Gas}

Law/UU no. 22 of 2001 article 1 states that Petroleum is the result of a natural process of hydrocarbons under conditions of atmospheric pressure or temperature in the form of liquid or solid phases, including as phalt, mineral wax or ozokerite, and bitumes obtained from the mining process, but excluding coal or other solid hydrocarbon deposits obtained from activities not related to Oil and Gas business activities.

Natural gas is the result of a natural process in the form of hydrocarbons under conditions of atmospheric pressure and temperature in the form of gas phases obtained from oil and gas mining processes. While the meaning of oil and gas itself according to Experts argue that petroleum is formed from decaying the remains of ancient life (animals, plants, and microorganisms) are buried with sea water and into sandstone, clay, or limestone contained in the layer of the earth's crust for millions of years through physics and chemistry.

Based on the theory of Biogenesis, petroleum is formed by the existence of a permanent small leak in the carbon cycle. This carbon cycle occurs between the atmosphere and the surface of the earth, which is represented by two arrows in the opposite direction, where carbon is transported in the form of carbon dioxide (CO2).

It can be concluded from the explanation of both that oil and gas is part of the environment, so in managing it must consider the appropriate balance to preserve the environment in addition to taking the benefits of the environmental results. Do not let the industry built by the government, especially oil and gas disturbing and even damaging the environmental sustainability. Which in this case the preservation of the environment is much more in priority because to maintain the viability of ecosystems that have lived and developed longer than the establishment of industries that have been approved by the government

\section{The Negative Impact of Oil and Gas on the Environment}

It is undeniable that the mining industry of the oil and gas sector (Oil and Gas) provides economic benefits and huge state revenues for Indonesia. Oil and gas is a strategic, nonrenewable natural resource - and as an energy source in this country where the results of oil and gas processing are fuel for motor vehicles. In the electricity sector, oil and gas is also required with the presence of Gas Power Plant. In the last five years, the energy and mineral resources sector accounted for an average of $20-30 \%$ of total state revenues. Where most of it is sustained by oil and gas sector.

On the other hand, the impact of the oil and gas industry is a matter of environmental sustainability. Oil and gas industry is often a major problem in environ mental pollution. Oil and gas business activities are divided into two: upstream business activities and downstream business activities. Upstream business activities include: exploration and exploitation. While downstream business activities include: processing, transportation, storage, and trade.

This upstream oil and gas industry is full of risks to aspects of environmental sector issues. In the upstream activities, oil and gas exploration and exploitation occurs in the high seas. This is often the source of environmental pollution. It is the responsibility of oil and gas business entities to preserve the environment after min ing exploration. The responsibility for environmental protection aims to protect the territory of the Unitary State of the Republic of Indonesia (NKRI) and also the survival of human life.

According to Otto soemarwoto, a leading ecologist defines it as follows: The environment is the sum of all things and conditions that exist in the space we occupy that affect our lives. According to Moenadjat Danusaputro, an eminent environmental biologist and professor of the university's legal college, defines the environment as all things and conditions, including human beings and their actions, contained in space [1]. The place where man lives and influences the life and well-being of human beings and other living bodies, in this case the plants and animals. According to juridical understanding, as provided by law on the basic provisions of environmental management no. 4 of 1992 (hereinafter referred to as UUPLH 1982), the environment is defined as the unity of space with all objects, 
styles and circumstances and living things, including human beings and their behavior that affect the survival of the life and welfare of human beings and other living beings [2].

Of the three theories above, it can be concluded that the environment is that environmental sustainability is determined by human behavior, because all human behavior towards the environment greatly affects the totality of good environmental conditions including the sustainability of animals and plants.

\section{Principles of Environmental Management}

UUPLH 1997 lays down the principle of management of the circle which in its formula explicitly listed 3 principles. The basic as sumptions can be seen in article 3 as follows:

The management of the environment which is carried out with the principle of State responsibility, sustainable principle, and the principle of benefit aims, realizing sustainable development that is "Environmentally minded" in the context of the development of the whole Indonesian people as well as the building of the whole community who believe and piety to God Almighty.

The three principles are:

1. The principle of State responsibility;

Through this principle on the one hand, the State guarantees that the utilization of natural resources provides optimal benefits to the public, followed by quality (life quality), while on the other hand the State has the power to take preventive and repressive actions against the activities that harm the environment, the individual and the community or the population.

\section{Susteainable principle;}

Article 3 is called by the principle of the continuing meaning that everyone carries the responsibility and obligation for future generations, as well as with each other in a generation.

3. The principle of usage aims to promote sustainable development.

The development of environmentally sustainable development is a conscious and planned effort that integrates the environment, including resources, into the development process to ensure the capacity, welfare and quality of life of present and future generations. As has been explained by the existence of obligations and responsibilities then the environmental capability must be preserved. Sustainability of he ability to live becomes a pedestal to continue development.

\section{E. Environmental Provisions}

The obligations of business entities, including those engaged in the oil and gas industry, to preserve the environment are strictly regulated in the life environment/ LH Law, as follows:

a. prohibited from violating the quality and standard criteria of environmental damage;

b. shall have an analysis of environmental impacts, for a business plan and / or activity likely to have significant impacts on the environment; c. shall conduct waste management of business result and / or activity;

d. shall be responsible for the management of hazardous and toxic materials.

Against business entities that violate the regulated provisions, the Law on Environmental Protection Law has also been regulated on the system of sanctions imposed, namely as follows:

a. Admin istrative sanctions, as set forth in Article 25 paragraphs (1) and (2) and Article 27 paragraph (1) of the LH Law, are as follows:

- Prevent and end the occurrence of violations;

- Resolve the consequences of an offense;

- Carry out rescue, mitigation, and / or recovery measures at cost expense;

- Payment of a certain amount of money;

- Revocation of business license and / or activity.

b. Criminal sanctions, as provided for in articles 4147 of the LH Law.

\section{F. Examples of Oil and Gas Industry Cases that do not} preserve the Environment

1. Environ mental Pollution by Lapindo Brantas Inc., in Porong, Sidoarjo Regency of East Java

Since 2006, Lapindo Brantas Inc.'s gas pipeline, located in Porong, has leaked and extracted mud and hot water instead of oil or gas, polluting the Porong River. Conditions are still ongoing, even worse.

In fact, Lapindo Brantas, Inc., in 2004, received a red rating in the Corporate Performance Rating Program in environmental management throughout 2003. This red rating is awarded to business entities that have carried out control and pollution and / or environmental damage efforts but has not reached the minimum requirements as regulated in the prevailing laws and regulations. Lapindo Brantas Inc. It meets the Wastewater Quality Standard and the Emission Quality Standard, but has not submitted B3 waste permits.

2. Environ mental Pollution on Biawak Island, Indramayu Regency

The island of Biawak in Indramayu is polluted by waste from one of the oil and gas industries operating in Indramayu. This causes the disruption of water ecosystems in the area, but it also causes death of the fish and the declining quality of water, thus harming the surrounding community.

3. Environmental Damage Due to Mining Activities By PT. Freeport Indonesia

Freeport always claims to be committed to strong environmental management. Despite having ISO 14001 recognition and claiming to have a comprehensive program in monitoring acid mine water, Freeport proved to have no environmental responsibility. The company operates without transparency and does not comply with existing environmental regulations. Regardless of the need to provide public access to information related to the environment, Freeport has never announced its important documents, including the Environmental Risk Assessment. Freeport has also not 
published a three-year independent external audit report since 1999, as required by Amdal. Thus the company violates environmental clearance requirements.

The visible impact resulting from Freeport waste is no less amazing. Tailings production of 220,000 tons per day over the past 10 years resulted in the destruction of productive areas of forest, rivers and wetlands of 120,000 hectares, Freeport will still operate until 2041. If production levels remain, it will reach 225,000 to 300,000 tons of ore per day. In addition, Freeport is also unable to process its waste either rock waste, tailings to acid mine drainage.

Until the year of 2005, at least about 2.5 billion tonnes of Freeport waste of rocks were dumped into the wild. This resulted in the decline in environmental carrying capacity around the mine, as evidenced by landslides repeatedly occurred in the area. Even one of the members of the House of Representatives Panja for Freeport case found the fact that lands lide accidents due to waste of ock occur routinely every three years. This waste of rocks have been stockpiling Wanagon lake. A number of lakes pink, red and orange upstream areas have been lost, Cartstenz pasture is also dominated by other waste rock mounds which in 2014 is expected to reach a height of 270 meters and cover an area of $1.35 \mathrm{~km} 2$. Erosion of stone waste has contaminated the mountain waters and unstable rock waste mounds have caused a number of accidents.

Much of the freshwater life along the watershed entering the tailings has been destroyed by pollution and habitat destruction. Freeport has violated Government Regulation No.82 of 2001 on water quality management and water pollution control. Article 11 states that water pollution is the introduction or inclusion of living things, substances, energy and / or other components into the water by human activities, so that the quality of the water down to a certain level that causes water can not function in accordance with its designation.

\section{G. Corporate Social and Environmental Responsibility}

Considering the fact that the oil and gas industry sector is still causing environmental damage, the government gives strict regulation to the obligation of oil and gas industry to maintain the environment. This is regulated in Article 74 paragraph (1) of the PT Law, which read as follows:

"The Company which carries out its business activities in the field and / or related to natural resources is obliged to carry out the Social and Environmental Responsibility."

In addition, in order to ensure that the oil and gas sector is truly implementing Corporate Social Responsibility, the Company Law also regulates the mechanism of sanctions, namely in Article 74 paragraph (3), which reads as follows:

"Companies that do not perform the obligations as referred to in paragraph (1) shall be liable to sanctions in accordance with the provisions of laws and regulations."

One form of sanction that can be imposed on the oil and gas industry that does not carry out Corporate Social and Environmental Responsibility is based on the rules in the LH Law.

\section{H. Space to sue}

The right to a healthy and good environment is contained in Article $28 \mathrm{H}$ of the 1945 Constitution, Article 9 Paragraph (3) of Law No. 39/1999 on Human Rights and Article 65 Paragraph (1) of Law No. 32/2009 on Environmental Protection and Management. Thus, the state (government) and the business actor shall be obliged to respect, protect and fulfill that right. "Society or environmental agency has the right to fight for that right. In fact, Article 66 of Law No $32 / 2009$ stipulates that every pers on who fights for the right to a good and healthy environment can not be prosecuted in criminal or civil suit.

Community channels or environmental agencies may also be used to fight for environmental rights related to indications of environmental pollution, silting of the river, damage to forest areas and others, may be non-legal and legal. For legal proceedings, it can take administrative, civil and criminal litigation. If through the lawsuit to the State Administrative Court, it can be by way of application or lawsuit for permission to be revoked, or an act against the law. When through the civil lane, how to calculate the loss of society, environmental losses. If through a criminal line, it can be seen from whether there are victims, such as people affected by disease, skin diseases or died, or dead animals, fish or other. Thus in fact many ways that can be used by the community or environmental agencies in order to participate in maintaining environmental sustainability.

\section{CONCLUSION}

One of the causes of environmental pollution is the existence of waste cases that can not be preserved by industrial companies, especially oil and gas in Indonesia. Governments should be more assertive in enforcing environmental laws and balancing on oil and gas activities by industry. So that the economy of the State will not be disturbed or hampered by the existence of the Environ mental Act.

Nature has the dominant function of environmental sustainability, so it is better for industrial companies especially oil and gas to minimize work accident of its employees and can operate the company's waste well so that it is beneficial for the survival of the universe. Based on an assumption that environmental protection and improvement is a subject matter that affects the welfare of mankind, plants and animals. And in helping the development of the economy around the world. "Only in a good environment human beings can develop maximally, and only with good human environment can develop well".

Indonesian laws and regulations have clearly regulated the social and environmental responsibilities required to the Oil and Gas Business Entity. Legislation already regulates it, after which it means the implementation of those rules. The Oil and Gas Business Entity should consider environmental aspects and benefits for people in addition to thinking about economic benefits alone. Through the implementation of environmental and social responsibility programs, it is expected that oil and gas companies especially in the upstream sector have an "ethics" in doing business actions. Conducting exploration and exploitation of oil and gas without forgetting the environmental sustainability and survival of mankind. If there is a Oil and Gas Business Entity 
found guilty of environmental pollution, it must be brave to take responsibility and compensate.

Nature and a healthy environment is the desire of every human being. How to care for the environment can be realized because of the human role as well. Hu mans who will make the environment and nature become damaged or sustainable. People and companies in this case the oil and gas sector both play a role to care for and protect the environment. Minimally, oil and gas business entities can minimize environmental pollution due to the impact of exploration for the sustainability of the environment.

Environmental sustainability is the responsibility of all human beings, including government and business entities. The oil and gas industry as one of the largest contributors to the country's foreign exchange, which is also closely related to the environmental aspects, has an obligation to help preserve the environment. Indonesian law does not provide arrangements which is clear and firm enough for oil and gas industry related to its obligation in preserving the environment.Various cases of environmental damage that occurred, caused by the oil and gas industry, is evidence that the existing rules have not been implemented maximally. It is expected that with the regulation on Corporate Social and Environ mental Responsibility, as regulated in the Law of PT, can become a reference for oil and gas industry to preserve the environment

\section{REFERENCES}

[1] N. H. T. Siahaan, Hukum Lingkungan dan Ekologi Pembangunan. Jakarta: Erlangga, 2004.

[2] N. H. . Siahaan, Hukum Lingkungan. Jakarta: Penerbit Pancuran Alam, 2006. 